\title{
Library Towers and the Vertical Dimension of Knowledge
}

\author{
Wouter Van Acker, Pieter Uyttenhove, and \\ Sylvia Van Peteghem
}

\begin{abstract}
Verticality, and related figures such as the tower, stack, or mountain, are commonly used as spatial metaphors to express the hierarchy that we apply to information and knowledge. But these metaphors that transform the vertical dimension of knowledge into words are also translated into library architecture. Different libraries include, or have been built in the form of, a tower. In these cases, verticality as a spatial metaphor is folded back onto the spatial and architectural field where it originated. Library towers transform verticality as a concept that conveys relations in knowledge into architectural language. The translation of verticality as a dimension of knowledge into architecture thus forms a strange double bind between space and knowledge. This article analyzes how libraries have expressed the vertical dimension of knowledge in their architecture and identifies different approaches that make the vertical dimension of knowledge architecturally present. The library of Ghent University (Belgium), by Henry van de Velde, includes a storehouse of books that has been completely accommodated in a tower. The architecture of the French National Library, by Dominique Perrault, plays with the metaphor of the tower in a semantic manner. Other libraries, such as the "Book Mountain" by MVRDV in Spijkenisse, exploit the book stack architecturally; and some libraries, such as The Netherlands Institute for Sound and Vision, by Neutelings Riedijk architects, do not build up but down, in the underground, to house their collections.
\end{abstract}

Hence we might speak, among men, of a true Babel complex: Babel was supposed to serve to communicate with God, and yet Babel is a dream which touches much greater depths than that of the theological project; and just as this great ascensional dream, released from its utili- 
tarian prop, is finally what remains in the countless Babels represented by the painters, as if the function of art were to reveal the profound uselessness of objects, just so the [Eiffel] Tower, almost immediately disengaged from the scientific considerations which had authorized its birth (it matters very little here that the Tower should be in fact useful), has arisen from a great human dream in which movable and infinite meanings are mingled: it has reconquered the basic uselessness which makes it live in men's imagination. (Koolhaas \& Mau, 1998, p. xxxii)

The vertical dimension of knowledge is most famously expressed in the myth of the Tower of Babel, a structure built by a people united by a single language that was eventually brought down by a "confusion of tongues" disseminated by God. The story may be interpreted as a reaction to humanity's hubris (its desire to build a stairway to heaven) or its refusal to obey God's commandment to populate the earth. As a consequence of God's intervention, construction is brought to a halt by destabilizing the very foundation on which the Tower is erected: that is, the universal language that allowed humanity to learn how to build in the first place. The construction of the tower comes to an end because the ground on which it is constructed is disturbed and shown to be insecure. The "deconstruction" of the Tower reveals, to quote Jacques Derrida, "an unfinished edifice whose half-completed structures are visible, letting one guess at the scaffolding behind them" (1985, p. 102).

Different visionaries, artists, and architects have taken up the architectural symbol of the tower as a way of reflecting on the possibility or impossibility of imposing a universal system or of edifying a new totalizing structure. The utopian plan for a World Centre of Communication (1913) drafted by the French architect Ernest Hébrard and the Norwegian-American sculptor Hendrik Christian Andersen had a Tower of Progress in its center that was conceived as an inverse tower of Babel. The giant broadcasting station for the World Press that it contained would enlighten the world with the "divine intelligence and genius of man" and arouse mutual understanding between nations (Andersen \& Hébrard, 1913). Influenced by the latter, the Belgian visionary Paul Otlet depicted his Mundaneum as a tower that would organize and transmit all knowledge of the world on the basis of the Universal Decimal Classification (UDC) system that he had invented with his colleague Henri La Fontaine. Otlet compared the UDC system to the common language that, in a lesser known version of the story of the Tower of Babel, God gives to the people on the Pentacost after a state of general confusion. ${ }^{1}$ Again, an information system, but of a cybernetic order, was applied by Nicolas Schöffer to his 327-meter-high Tour Lumière Cybernétique (1963) for Paris. Schöffer's tower would process information about changes in stock markets, temperature, and transportation in the city of Paris and translate the data in a chrono-dynamic sequence of light effects (Brook \& Dunn, 2011, p. 95). 
Besides these utopian proposals, various libraries have included, or have been built in the form of, a tower. Similar to the visionary towers noted above, they all use the vertical dimension to articulate a view on the construction, restructuring, or deconstruction of knowledge and language systems. This article analyzes how libraries have expressed the relation between knowledge and verticality in their architecture and identifies approaches that make the vertical dimension of knowledge architecturally salient. In other words, what interests us is how the vertical dimension of knowledge leads to different forms of architectural archetypes, especially of libraries.

In this context, the Booktower of Henry van de Velde at Ghent University (Belgium) is a clear example of a library that effectively functions as a tower and offers a useful starting point for our analysis. In the second section, we review four recent library projects that play with the metaphor of the tower. In the third section, we look at the difference between stacks of books and piled up books. And in the concluding section, we then further excavate the symbolic meaning of vertical libraries by looking at underground book and archive repositories and, in the opposite-and indeed extreme-vertical direction, at "information satellites" in outer space.

\section{The Booktower: The University Library of HenRY VAN DE VELDE}

In 1933, the Belgian architect Henry van de Velde, then seventy years old, designed a new library for Ghent University that is now commonly called the "Booktower" (fig. 1). The tower was Van de Velde's functionalist answer to the organizational problem of storing an ever-expanding library collection and making items quickly accessible for patrons. The library is exceptional in the way its tower functions exclusively as the library's sole storehouse. Elongated, vertical bands of glass dissect the brutalist concrete façade, and therefore reveal what that facade protects: a giant concrete bookcase with 45,000 meters of shelves that could accommodate a total of two million books. All the other functions of the library-reception, reading room, and offices-are located in an adjacent slender, horizontal structure. The tower was designed to be nothing less than a storage and retrieval machine. The original process for obtaining a book was that a request made at the reception next to the catalogue room was sent through a pneumatic pipe system to one of the circulation assistants who each supervised a section of four floors out of a total of twenty-three floors (Milis-Proost, 1997). While a one-person lift allowed the assistant to move quickly across different levels, a book lift brought the requested books to the reception for pick-up.

In addition to embracing the verticality of knowledge on a functionalist level, the Booktower also integrated this dimension in an urban context. Confidently, Ghent's new Parthenon, 64 meters tall, was sited on the city's acropolis, measuring itself against Ghent's three historic tow- 


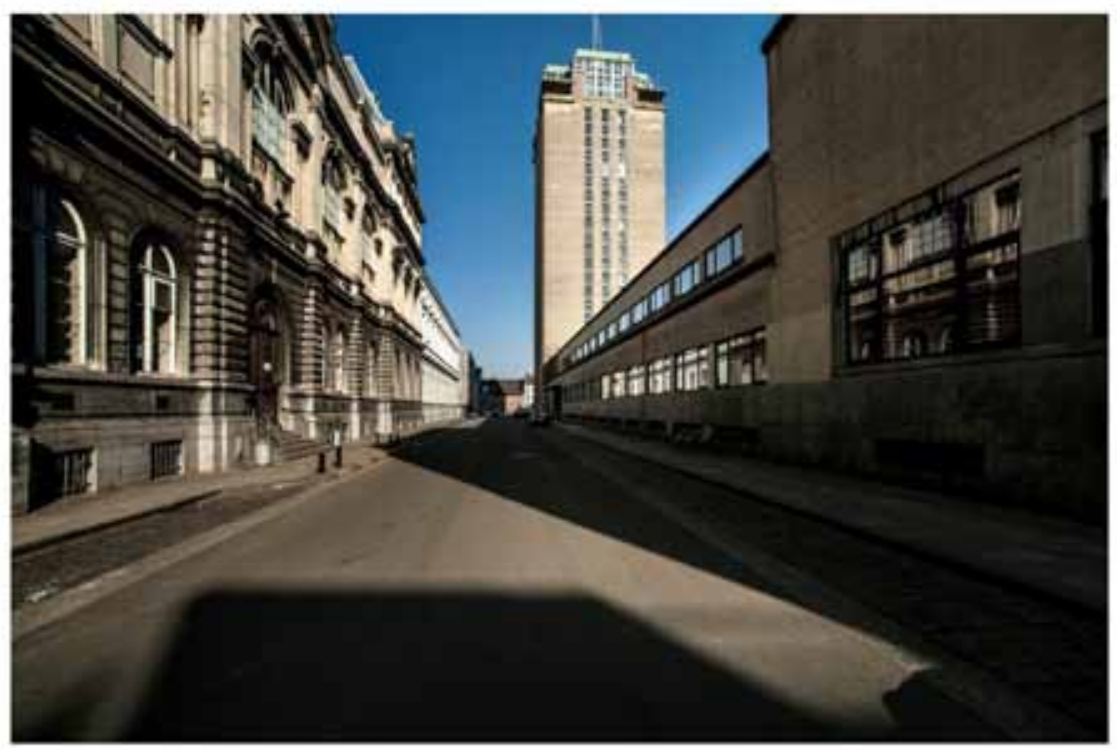

Figure 1. Henry van de Velde's booktower. The tower is the library's sole book warehouse. Photograph: Michiel Hendryckx.

ers a kilometer away-the town's bell tower, and the towers of the SaintNicolas church and Saint-Bavo's cathedral. The cruciform belvedere with its horizontal overhangs on the corner, reminiscent of Frank Lloyd Wright's architecture, provides an appropriate horizontal coronation. What was originally meant to function as a meeting room and museum of the book became an observation deck symbolizing the university's outlook over the city as well as over higher knowledge.

The tower concept was not only derived from the American skyscraper but also from American examples of vertical warehouses. Van de Velde was inspired by the public library of Los Angeles (1926) and the university library of Rochester (1930), which had also been realized in the shape of a tower (Baillieul, 1985, p. 164). René Apers, chief librarian at the time the Booktower was built, referred to American library towers in Chicago, Princeton, Toronto, and Yale. ${ }^{2}$ The Booktower resembled especially the tower of the Stirling Library of Yale University (1930), designed by James Gamble Rogers, in the way it tried to minimize the time of delivery and distance between books and readers by means of elevators and transport systems (University Library, 1934).

Like the Booktower, the university libraries of Cambridge (1934), London (1934), and Leuven (1928) were also built in the interwar period, inspired by American examples, and all included a tower. Yet, when one compares them with the Booktower, one sees how radical and innovative 
Van de Velde's design concept was (Devos, 2010). The university library of Leuven, reduced to ashes during the First World War, was rebuilt with American money donated by Herbert Hoover and designed by the American architect Whitney Warren. Based on the arrangement of the New York Public Library, the university library of Leuven accommodated its book warehouse in a separate structure of seven floors at the rear of the building, marking the front of the building with a monumental bell tower 80 meters high (Aerts \& Coppens, 1999, p. 144). The university library of Cambridge, designed by Sir Giles Gilbert Scott, included a tower only because the Rockefeller Foundation who sponsored the construction found that the initial design lacked bravura (Fox, 1998, p. 220). The tower, despite some formal similarities with the Booktower, functions partially as a warehouse and hosts those items of the collection for which there is little demand.

While American examples triggered Van de Velde to make the tower the focal point of the design, it seemed to have been the Swiss National Library (1930), realized according to the idiom of the "Neues Bauen," that had a major influence on the architectural expression of the Ghent University Library. The chief librarian and Kaufmann, one of the architects of the Swiss National Library, gave Henry van de Velde a guided tour in $1935 .{ }^{3}$ It is striking how many ideas about materiality, arrangement, and style were transferred from Bern to Ghent.

The Booktower was not the only library building designed by Henry van de Velde that included a tower. The Belgian pavilion that he designed for the 1939 New York's World's Fair was supposed to be shipped back home after the fair closed, but by that time Belgium was occupied by German forces. Therefore, the Belgian government decided to donate the building to Virginia Union University (Ploegaerts \& Puttemans, 1987, pp. 211, 412). The building accommodated the library, laboratories, and gymnasium of the American Institute of Higher Learning in Richmond. The pavilion with its thirty-five-bell carillon had large ceramic sandstone bas-reliefs at the bottom, one by Oscar Jespers and Henry Puvrez showing Belgians at work, and another by Arthur Dupagne depicting the Congolese population. The director of the Hoover Library and Archives recently stated that the belfry symbolizes the institution's ambition "to promote peace and personal freedom and to foster ideas that strengthen a free society" (Watkins \& Nelson, 2004).

\section{The Tower as Metaphor}

All library towers, even a functionalist design like Henry van de Velde's Booktower, are trapped in a process of semantic expansion. The tower, or campanile, is after all one of the basic semantic figures of architecture besides the amphitheatre, stoa, and basilica. James Stirling's plan for the Berlin Social Science Research Center (Wissenschaftszentrum Berlin für 
Sozialforschung, WZB) integrates these different architectural figures but reserves the tower for the library. The library tower takes a pivotal position in the plan, linking and providing services to the different research units of the WZB. The colorful wraparound wallpaper comments with humor on the perception that this research library is a place for scholars absorbed in thought. If the temperament of reason is melancholia, as famously depicted by Albert Dürer, Stirling emphasizes by contrast the joy of reinvention and reorganization. The library is as much a place of order as it is of disorder. Despite all catalogues that try to install an order of knowledge, the library also remains a Celestial Emporium of Benevolent Knowledge, to refer to Borges description of "a certain Chinese Encyclopaedia." The library's disorder, which includes "the present classification" as well as all others, is the playground for the librarian as well as the scholar.

A tower for books can never be a mere building but is always also a representation of knowledge. The library as tower is a metaphorical statement. Dominique Perrault won the international competition of 1989 for the French National Library with a design that takes advantage of that idea. On a former industrial wasteland along the Seine, Perrault places a giant platform with a sunken forest garden that redraws the area of Tolbiac and mirrors the park of Bercy at the other side of the Seine. At the corners of this huge rectangular base, he places in a Cartesian arrangement four L-shaped geometrical prisms of twenty-five stories. The towers each resemble a gigantic open book and are turned to each other to imply an invisible volume that unites them. The towers are not only accommodating the national collection of more than ten million volumes. They are a pars pro toto representing that national collection and by extension the collections of all libraries in France. Next to the Louvre pyramid and the Arche de la Défense, the French National Library is another of President Mitterrand's Grands Travaux; a metaphorical landmark representing Paris as the symbol of France. Perrault's super-library is the nation's ivory tower.

For the same competition of the French National Library or Très grande bibliothèque, the Office for Metropolitan Architecture (OMA) designed a 100-meter-tall cube-a solid block that is of such dimensions that it may be considered a tower. Yet unlike the tower, the cube remains silent and interiorizes all repetition and expansion. Also, unlike Perrault's design, OMA's cube does not integrate but dissociates itself from the urban context. As if it was a meteor that has landed on the banks of the Seine, the presence and bigness of the monolith express Rem Koolhaas's now famous maxim "Fuck context." The cube, unlike the Perrault's towers, remains silent on the outside and speaks about repetition and difference on the inside. Repetition is the act that fills the cube with information and organizes the national collections. Difference is introduced by means of voids that are carved out of this dense repository of images and words. These voids define embryonic 
public spaces, symbolic spaces that accommodate the persistent "desire for collectivity" (Koolhaas \& Mau, 1998, p. 604).

The Geisel Library at the University of California, in La Jolla, San Diego, symbolizes yet another aspect of the vertical dimension of books and knowledge. Built in 1970, the library is situated high above ground floor, positioned as a fortified stronghold at the head of a canyon, or as a spaceship that landed on a platform. Conceived by architect Robert A. Thorburn, from the canyon below the building seems unapproachable. The books, and the knowledge they contain, appear inaccessible in spite of the wide glass facades. Here, knowledge is of a "higher" order, and all those who have access to it get an elevated view on the world.

\section{PILING UP BoOKS}

Booktowers are invested with an even more metaphorical dimension when the books themselves are used as building components. Towers as built forms of monumental architecture are then made of stacks or piles of books. The question arises if a building can be made of books. Stacks of books demonstrate an immediate physical link between books but refer also to the fragile equilibrium of this mode of building. Stacks are temporary or even casual constructions of books awaiting further manipulation or a more permanent destination. Piling up books is more about a compact manner of conservation than about making the books accessible to the public.

The symbolism of stacked books has sometimes been combined with the effective utility that represents a compact way of conserving books. "Book Mountain" is a 2012 project by the architectural office MVRDV in Spijkenisse in the Netherlands. This tower of books where all books are visible is freely accessible to the public and is situated under a pyramidshaped glass roof. The new British Library in London, which opened in 1997, contains at its heart The King's Library Tower. This glass tower contains King George III's collection composed of thousands of precious books. The glass tower has the aspect of a shrine, displaying its content, but unattainable for the uninitiated. A similar glass tower of books, preceding that in the British Library, was conceived and built by Architect Gordon Bunshaft and sculptor Isamu Noguchi in 1963. It is placed at the center of the Beinecke Rare Book \& Manuscript Library at Yale University. Some libraries opt for the opposite strategy, hiding their storage and making it inaccessible directly. The planned Newspaper Storage Building at Boston Spa, in West Yorkshire, England, for instance, will be a huge repository for the British Library's collection of newspapers enclosed and stowed away in a hermetically closed space of 64 by 24 by 24 meters. It will be outfitted with robotic shelving, and monitoring of temperature, humidity, light, and oxygen levels will make it unnecessary for humans to go inside.

Not only architects but also artists have worked with the image of stacks 
and piles of books. Some of them suggest the possibility of ascending to unattainable heights. But implicitly they also embrace in their work the miscellanea of domains, genres, formats, and all kinds of books, texts, and information. In stacks of books we see represented the speculative aspect of information, facts, and fiction. The Tower of Babel is the figure that Marta Minujin was alluding to when she built a spiral of thirty thousand books on San Martin square in Buenos Aires in 2011. The spiral shaped stack of books makes us think of the antique figure of the Babel ziggurat, or the endlessly expansible museum conceived by Le Corbusier in the thirties. In Prague in 1995, Matej Kren erected a tower of books where you could go inside. The Lincoln Tower of Books in Washington D.C. consists of approximately seven thousand books all about Abraham Lincoln, the sixteenth president of the United States. The stacked books form a hollow circular tower that rises over several floors as a huge chimney in the center of a round staircase.

\section{The Abyss is THE Limit}

We conclude this article with a section that explores the extremes of the vertical dimension of knowledge; in other words, what lies beyond the library tower. While the library as tower seems to convey the message that it is able to contain and structure all knowledge through vertical expansion, that expansion is most likely to occur not at the top of the building but, as long as soil conditions permit, at subterranean levels. Extending the library's basement by excavating underground provides not only a solution to space shortage but also enables libraries with valuable heritage collections to keep them in the best possible and safest conditions. Of course, when building below ground, conditions for preservation are of paramount importance, but much consideration should also be given to providing systems that ensure the speedy retrieval of items. The collection must stay within reach, and compact storage seems to be a valuable solution to achieve this. Going underground with compact storage systems has other advantages. It can be built fast, and the space required, just like a wine cellar, can be small; maintenance costs are low; and stable temperature, of capital importance in such an environment, is easy to control (think again of the wine cellar).

Four striking European examples prove that this is a strategy worth considering. In these recent projects and renovations, the abyss rescues the tower and reverses the mechanism of verticality. A work in progress is the construction of a three-story deep repository under the inner garden of Henry van de Velde's Booktower in Ghent, supervised by Robbrecht and Daem Architects. It will host 40 kilometers of shelving. To reach the inner court, a special road had to be dug under an existing building. The British Library, designed by Sir Colin Saint John Wilson, moved into its new building at St. Pancras in London in 1997. It has many underground 
floors, housing kilometers of shelving. The National Library of Finland in Helsinki, designed by Laiho-Pulkkinen-Raunio architects, which also houses university collections, was completed in 2001 and includes a 57,600 cubic meter underground bunker drilled in solid rock, 18 meters deep. This amazing construction can be reached from different locations in the city and is called "Kirjaluola" (Bookcave). The Netherlands Institute for Sound and Vision, by Neutelings Riedijk architects, chose a repository with a view: a 16-meter deep canyon with five underground terraces, hosting eight hundred thousand hours of audiovisual material. The building was completed in 2006 and was spectacularly built on water.

We can conceptualize the storage of all scientific endeavor on a vertical axis, rising from the depths of the labyrinthine knowledge abyss to high in the sky. Abyss and sky would appear to represent the limits of any vertical system of storage. But what if we extended the upper limit into the cosmos. In relation to this, beyond communication satellites orbiting the earth, we might think of the space probes Voyager 1 and Voyage 2, launched by NASA in 1977. Inside both probes there is a gold gramophone record that portrays humanity by means of music, pictures, and messages recorded in fifty-five languages, one of these being President Carter inviting aliens from distant worlds to form a community of Galactic civilization. Photographs of a nude man and women were in the end censored by NASA. This encyclopedic "message in a bottle" followed earlier messages sent by NASA into the Great unknown (Bellows, 2005). Pioneer 10, launched in 1972, carries an engraving on a gold metallic plaque, measuring 6 by 9 inches, which acts as humanity's business card. It depicts a naked couple, symbolizing humanity and the solar system, indicating the position of the Earth, the trajectory of the space probe, and the rhythm of pulsars that uniquely identify our sun.

\section{Conclusion}

The tower is an architectural metaphor that is essential to library science. One could argue that it symbolizes library science because it expresses the subject's "architectural" project of constructing a universal language that structures and orders all information. Verticality is a specification of the more general metaphor of building. It is the mechanism that applies hierarchy to information and knowledge. The use of the tower as an architectural metaphor for the vertical dimension of knowledge is thus far from innocent. If defining secure ground for the edifice of knowledge is the foundational question of library science, then establishing hierarchical order is what that vertical edification process is all about.

The vertical architecture of knowledge has to do with explaining knowledge, with making parallel or serial connections and links, or explaining the hierarchy between high and low. The arrangement resulting from using different heights or relations as above and below is analogous 
to the epistemological dimension that makes a difference between higher and lower knowledge. The first relates to scientific, religious, argued, or speculative knowledge developed by men using wisdom and inventiveness; the second to everyday, utilitarian, mostly practical, experiencebased, directly operable knowledge. There is an unmistakable symbolic meaning in the vertical dimension of knowledge and information, and one should not be surprised that higher knowledge should be situated close to the unreachable, unapproachable, heavenly or divine; whereas lower, "down to earth" knowledge is located closer to, or at, ground level. This symbolism revolves around tensions between highbrow and popular knowledge; between idealism and materialism; and between knowledge that is recent, accessible, and open and that which is forgotten, hidden, and secret.

But the translation between architecture and library science also works in the other direction. Once the vertical dimension of knowledge is translated into library architecture, the metaphor of the tower is folded back into the architectural field where it originated. Library towers in their turn transform verticality as an epistemological concept into architectural language. Library towers may use architecture to reveal, hide, or neglect the structure and order of library systems. A library tower becomes at the same time a presence and representation of the library's systems of knowledge organization.

The translation of verticality as a dimension of knowledge into architecture thus forms a strange double bind between space and knowledge, if not a Gordian knot. This never-ending process of translation between architecture and the organization of knowledge brings to mind the myth of the Tower of Babel. The tower stands at once as the fundamental incompleteness of knowledge as building, but also of building as the possibility for ordering knowledge.

\section{Notes}

1. Paul Otlet, La langue, Archives of the Mundaneum, fonds EUM, farde EUM73, doc nr 8402.

2. Manuscript section, Ghent University Library, BHSL.HS.III.0128/V20 (box 81, folder "nota's anderebibliotheken").

3. Manuscript Room, Ghent University Library, Letter of Henry van de Velde to Monsieur Magnel, 4 February 1935.

\section{REFERENCES}

Aerts, D., and Coppens, C. (1999). Leuven in books, books in Leuven: The oldest university of the Low Countries and its library. Leuven: Universitaire Pers Leuven.

Andersen, H. C., and Hébrard, E. M. (1913). Création d'un Centre Mondial de Communication. Paris: Philippe Renouard.

Baillieul, B. (1985). Een toren voor boeken: 1935-1985: Henry Van de Velde en de bouw van de Universiteitsbibliotheek en het Hoger Instituut voor Kunstgeschiedenis en Oudheidkunde te Gent : tentoonstelling 26 oktober-24 november 1985, Centrale Bibliotheek Rijksuniversiteit Gent, Hoger Instituut voor Kunstgeschiedenis en Oudheidkunde, Gent. Gent: RUG. 
Bellows, A. (2005). NASA's messages to the Great Unknown. Retrieved June 13, 2013, from http://www.damninteresting.com/nasas-messages-to-the-great-unknown/

Brook, R., and Dunn, N. (2011). Urban maps: Instruments of narrative and interpretation in the city. Farnham, Surrey: Ashgate.

Derrida, J. (1985). Jacques Derrida: Reply. In Christie V. McDonald (Ed.), The ear of the other. New York: Schocken Books.

Devos, A. (2010). De Boekentoren en haarlotgenoten Eenvergelijkendestudietussendrietorenbibliotheken. Unpublished master's thesis, Ghent University.

Fox, P. (1998). Cambridge University Library: The great collections. Cambridge, UK: Cambridge University Press.

Koolhaas, R., and Mau, B. (1998). S, M, L, XL: Small, medium, large, extra-large. New York: Monacelli Press.

Milis-Proost, G. (1997). De Gentse Universiteitsbibliotheek als embleem van moderniteit. Gent: Universiteitsbibliotheek Gent, Universiteit Gent.

Ploegaerts, L., \& Puttemans, P. (1987). L'oeuvre architecturale de Henry Van de Velde. Brussels: Atelier Vokaer.

Watkins, E., \& Nelson, D. (2004). Bells for peace. Retreived June 13, 2013, from http://www .bellsforpeace.org/eastWestConnection.htm

University Library (1934). The Architectural Review, 76(456), 168-176.

Wouter Van Acker is a lecturer at the Griffith School of Environment (Architecture) where he teaches architectural history and contemporary architecture. His research focuses on the intellectual and transnational history of nineteenth- and twentiethcentury architecture and the spatial way in which information and knowledge is organized, represented, and disseminated. He obtained the Degree of Civil Engineer-Architect (Ghent University, 2004) and the Degree of Doctor in Engineering: Architecture (Ghent University, 2011). In his doctoral dissertation, he studied the visionary schemes and schemas of the Belgian internationalist and encyclopaedist Paul Otlet (1868-1944). He recently edited a book on the Universal Exhibition that took place in Ghent in 1913 and edited an issue of Library Trends (61[2], Fall 2012) on "Information and Space: Analogies and Metaphors."

Pieter Uyttenhove is full professor at the Department of Architecture and Urban Planning of Ghent University, where he is currently head of department. He was trained as an engineer-architect at the University of Leuven (1980), studied urban planning at the Institut d'Urbanisme de Paris (1982), and received his doctorate in art history at the École des Hautes Études en Sciences Sociales (EHESS) in Paris (1999). He is director of doctoral research in theory and history of urban planning, codirector of the Research Laboratory for Urban Design, Labo S, and founder of Studio Open City. He has published extensively in international journals and magazines. Among other books, he is editor of Recollecting Landscapes (2006), and author of Marcel Lods: Action, Architecture, Histoire (2009), Stadland België (2011), and Beaudouin et Lods (2012).

Sylvia Van Peteghem is director of libraries at Ghent University. She holds a PhD in Dutch literature (1994) and a master in information science (1986). She is active in international organizations on library architecture (Liber Architecture) and open access (SPARC, OPENAIRE). The library is part of the research department of the university, and its role is fourfold. It is the center of the library network; the digital library in all its aspects; and the repository library for a rich cultural heritage, which made it a Google Books partner. Last but not least it offers a working place in the wonderful Booktower of Henry van de Velde. 